ISSN 1678-3921

Journal homepage: www.embrapa.br/pab

For manuscript submission and journal contents, access: www.scielo.br/pab

\section{Performance of soybean grown in succession to black oat and wheat}

\begin{abstract}
The objective of this work was to evaluate the influence of isolated or combined roots and straw of black oat and wheat, as previous crops in autumn/winter, on the performance of soybean in succession. The experiment was carried out in the 2017/2018 and 2018/2019 crop seasons in a randomized complete block design, with four replicates. The following seven treatments were applied in the autumn/winter of 2017 and 2018, before soybean planting: fallow; straw of black oat or wheat, distributed on plots kept under fallow during autumn/winter, without roots; plots only with roots of black oat or wheat, without straw; and plots with straw and roots of black oat or wheat. Soybean crop performance was estimated using the following variables: plant density, leaf area index, soil plant analysis development (SPAD) index, shoot dry matter, grain yield, and yield components. In comparison with fallow, the cultivation of black oat or wheat, as previous crops during the autumn/winter, increases soybean grain yield. The impact of the roots of black oat or wheat on soybean yield is similar to that of straw. Soybean agronomic performance is improved in the combined presence of roots and straw of black oat or wheat.
\end{abstract}

Index terms: Avena strigosa, Glycine max, Triticum aestivum, cover crops, no-tillage.

\section{Desempenho de soja cultivada em sucessão à aveia-preta e ao trigo}

Resumo - O objetivo deste trabalho foi avaliar a influência de raízes e palha, isoladamente ou combinadas, de aveia-preta e trigo, como culturas prévias no outono/inverno, sobre o desempenho da cultura de soja em sucessão. O experimento foi conduzido nas safras de 2017/2018 e 2018/2019, em delineamento de blocos ao acaso, com quatro repetições. Foram aplicados os seguintes sete tratamentos no outono/inverno de 2017 e 2018, antes do plantio da soja: pousio; palha de aveia-preta ou de trigo distribuída em parcelas mantidas em pousio durante o outono/inverno, sem a presença de raízes; parcelas apenas com raízes de aveia-preta ou de trigo, sem a presença de palha; e parcelas com palha e raízes de aveia-preta ou trigo. O desempenho da cultura de soja foi estimado pelas seguintes variáveis: densidade de plantas, índice de área foliar, índice "soil plant analysis development" (SPAD), massa seca da parte aérea, produtividade de grãos e componentes do rendimento. Comparativamente ao pousio, o cultivo de aveia-preta ou trigo, como culturas prévias durante o outono-inverno, aumenta a produtividade da soja em sucessão. $\mathrm{O}$ impacto das raízes de aveia-preta ou trigo na produtividade da soja é semelhante ao da palha. O desempenho agronômico da soja é melhor na presença combinada de raízes e palha de aveia-preta ou trigo.

Termos para indexação: Avena strigosa, Glycine max, Triticum aestivum, culturas de cobertura do solo, plantio direto. 


\section{Introduction}

The no-tillage system shows significant ecological, economic, environmental, and social benefits when compared with conventional tillage (Derpsch et al., 2014), especially under cropping systems with a high plant diversity and biomass production (Franchini et al., 2012). However, in Brazil, agricultural areas under fallow between two soybean [Glycine max (L.) Merr.] crop seasons, from March to September, are still common. Cropping systems with a low diversity and low addition of biomass, such as that of fallow/ soybean, have been pointed out as the major cause of soil degradation under no-tillage (Munkholm et al., 2013; Calonego et al., 2017).

In Southern Brazil, an important alternative for the autumn/winter period is to sow black oat (Avena strigosa Schreb.) as a cover crop or for fodder production in the crop-livestock system (Balbinot Junior et al., 2009). Black oat has a great capacity for dry matter production, resulting in an adequate soil cover under no-tillage (Pissinati et al., 2016), high nutrient cycling (Wolschick et al., 2016), and weed suppression (Balbinot Junior et al., 2011). In addition, the species can be easily desiccated for planting of the subsequent crops (Krenchinski et al., 2018). Another crop that can be used in the autumn/winter season is wheat (Triticum aestivum L.), which has positive effects on soybean growth, compared with corn (Zea mays L.) and fallow (Yokoyama et al., 2018).

The beneficial effects of black oat and wheat as previous crops on soybean performance may be attributed to their roots and straw. Roots can improve soil physical quality (Ferreira et al., 2018), leading to an increase in soil water infiltration and retention, improved oxygen diffusion, and reduced soil resistance to root penetration. Straw reduces the soil water evaporation rate (Dahiya et al., 2007), the peaks of soil heating (Dalmago et al., 2010), weed infestation (Balbinot Junior et al., 2011), and soil erosion (Engel et al., 2009), also releasing nutrients to the subsequent crops (Calonego et al., 2012). However, despite these benefits, many farmers still remove the biomass from the cropping area to use the straw produced by black oat and wheat as hay or silage.

The objective of this work was to evaluate the influence of isolated or combined roots and straw of black oat and wheat, as previous crops in autumn/ winter, on the performance of soybean in succession.

\section{Materials and Methods}

The study was carried out in the municipality of Londrina, in the state of Paraná, Brazil $\left(23^{\circ} 12^{\prime} \mathrm{S}\right.$, $51^{\circ} 11^{\prime} \mathrm{W}$, at an average altitude of $585 \mathrm{~m}$ ), in the 2017/2018 and 2018/2019 crop seasons. The soil was identified as a Latossolo Vermelho Distroférrico, according to the Brazilian classification (Santos et al., 2013), corresponding to a Rhodic Hapludox (Soil Survey Staff, 2010), with the following attributes at the 0.00-0.20-m depth, prior to the setup of the experiment: $750 \mathrm{~g} \mathrm{~kg}^{-1}$ clay; $16.8 \mathrm{~g} \mathrm{dm}^{-3}$ organic carbon; $5.1 \mathrm{pH}$ in $\mathrm{CaCl}_{2} ; 13.9 \mathrm{mg} \mathrm{dm}^{-3} \mathrm{P} ; 0.59,4.2$, and $2.0 \mathrm{cmol}_{\mathrm{c}} \mathrm{dm}^{-3}$ $\mathrm{K}, \mathrm{Ca}$, and $\mathrm{Mg}$, respectively; and base saturation of $58 \%$. The soil had been managed under no-tillage for ten years, with the planting of soybean in summer and of wheat or black oat in winter. According to KöppenGeiger's classification, the climate of the region is subtropical humid (Cfa), with an annual average temperature of $21^{\circ} \mathrm{C}$ and mean maximum and minimum temperatures, respectively, of $28.5^{\circ} \mathrm{C}$ in February and $13.3^{\circ} \mathrm{C}$ in July. The average annual precipitation is $1,651 \mathrm{~mm}$, with January being the wettest month (217 $\mathrm{mm})$ and August, the driest $(60 \mathrm{~mm})$.

The experiment was laid out in a randomized complete block design with four replicates. The following seven treatments were applied during the 2017 and 2018 autumn/winter seasons, before soybean planting: fallow (1); straw of black oat or of 'BRS Pardela' wheat, distributed on plots kept under fallow in the winter, without roots (2 and 3); plots with roots of black oat or wheat, without straw (4 and 5); and plots with straw and roots of black oat or wheat (6 and 7). The treatments were repeated in the same plots in both crop seasons. The plots measured $8.0 \mathrm{~m}$ in length and $5.0 \mathrm{~m}$ in width, and the area used for the evaluations was of $9.0 \mathrm{~m}^{2}$ (6.0 m long x $1.5 \mathrm{~m}$ wide). Black oat and wheat were mechanically sown in April 2017 and 2018, using a tractor-pulled seeder with 13 rows at a $17-\mathrm{cm}$ spacing, double disks as furrow openers for fertilizer and seed deposition, helical fertilizer metering mechanism, and fluted wheels for seed metering. For both winter crops, the seeder was adjusted to distribute 350 seeds per square meter at a $3.0-\mathrm{cm}$ depth, aiming densities of 300 plants per square meter. Wheat was managed as a cash crop, receiving $250 \mathrm{~kg} \mathrm{ha}^{-1}$ of the 5-20-10 N-P ${ }_{2} \mathrm{O}_{5}-\mathrm{K}_{2} \mathrm{O}$ fertilizer, whereas black oat was not fertilized once it was grown as a cover crop. In the fallow plots, there was a reduced weed infestation by sourgrass [Digitaria 
insularis (L.) Fedde] and hairy fleabane (Conyza spp.), which were controlled in August 2017 and 2018. In September, all plots were desiccated with 1,080 g a.e. ha $^{-1}$ glyphosate plus mineral oil. Early in October 2017 and 2018, straw was manually removed from the plots that should contain only roots of black oat or wheat (treatments 4 and 5), being redistributed on the plots where only straw would be used (treatments 2 and 3) in the autumn/winter period.

The soybean cultivar BRS 1003IPRO of indeterminate growth and from maturity group 6.3 was sown on $10 / 4 / 2017$ and $10 / 17 / 2018$, using a tractorpulled seeder operating at an average speed of $5 \mathrm{~km} \mathrm{~h}^{-1}$, equipped with five rows at a $45-\mathrm{cm}$ spacing, guillotinetype shanks and double disks as furrow openers for fertilizer and seed deposition, respectively, helical fertilizer metering mechanism, and horizontal plates as seed meters. The seeder was adjusted to distribute 37 seeds per square meter at a $5.0-\mathrm{cm}$ depth, aiming the establishment of 30 seedlings per square meter. Soybean seeds were treated with $150 \mathrm{~mL}$ VitavaxThiram 200 SC, $100 \mathrm{~mL}$ Co-Mo Platinum, and 100 $\mathrm{mL}$ of the liquid inoculant Gelfix 5 per $50-\mathrm{kg}$ bag of seeds. Fertilization consisted of $300 \mathrm{~kg} \mathrm{ha}^{-1}$ of the formula 0-20-20 N- $\mathrm{P}_{2} \mathrm{O}_{5}-\mathrm{K}_{2} \mathrm{O}$, applied into the seeding furrow, $5 \mathrm{~cm}$ below and aside from the seeds. The control of pests, diseases, and weeds was performed according to the technical recommendations for the crop. The sequential water balances for the 2017/2018 and 2018/2019 crop seasons are shown in Figure 1.

At the time of soybean sowing, the amount of straw produced by both black oat and wheat was evaluated in $1.0 \mathrm{~m}^{2}$ per plot. The samples were oven-dried at $65^{\circ} \mathrm{C}$, weighed, and redistributed on the plots. Soybean performance was estimated using the following variables: soybean plant density, determined in the V2 stage (Fehr \& Caviness, 1977) in $3.0 \mathrm{~m}^{2}$ per plot; leaf area index (LAI), evaluated in the R1 and R4 stages in 2017/2018 and in R2 and R5.2 in 2018/2019, using the LAI-2200 plant canopy analyzer (LI-COR Biosciences, Lincoln, NE, USA); soil plant analysis development (SPAD) index in R1 and R4 in 2017/2018 and in R2 and R5.2 in 2018/2019, determined in the central leaflet of the third open trefoil from the apex to the base of ten plants per plot, using the SPAD-502 chlorophyll meter (Konica Minolta Sensing Inc., Osaka, Japan), which applies parts of the red and infrared light spectra to estimate chlorophyll content; shoot dry matter, in R1 and R4 in 2017/2018 and in R2 and R5.2 in 2018/2019, by collecting and oven-drying, at $65^{\circ} \mathrm{C}$, the plants present in $1.0 \mathrm{~m}^{2}$ per plot; grain yield, evaluated by harvest of $6.75 \mathrm{~m}^{2}$; and yield components, assessed for 15 plants per plot.

The data were tested for normality by ShapiroWilk's test and for homoscedasticity of variances by Bartlett's test. After these assumptions were verified, the data were subjected to the analysis of variance, and the means values were compared by Scott-Knott's test, at 5\% probability, using the Sisvar, version 4.2, software (Ferreira, 2008).

\section{Results and Discussion}

The soybean stand of 300 and 350 thousand plants per hectare in 2017/2018 and 2018/2019, respectively, was not affected by all treatments, although the climatic conditions in both crop seasons were very different. In the first season, water availability was adequate throughout the soybean development cycle. However, in the second, two periods of water deficit occurred, one during flowering and the other during grain filling (Figure 1).

In the 2017/2018 crop season, the presence of straw, roots, or straw plus roots of wheat reduced the LAI and the biomass of soybean in the R1 stage, in comparison with the other treatments (Table 1). In the R4 stage, the treatment straw plus roots of wheat led to the lowest soybean LAI, whereas fallow and wheat straw decreased soybean biomass. However, in R1 and R4, the SPAD index was not influenced by any of the treatments. These data show that soybean growth was lower after wheat than black oat. Yokoyama et al. (2018) also observed a lower vegetative growth of soybean plants sown after wheat, compared with corn, Crotalaria spectabilis Roth, and Urochloa ruziziensis (R.Germ. \& C.M.Evrard) Morrone \& Zuloaga; however, this effect was greatly influenced by the crop season.

In 2018/2019, the treatments did not affect the LAI and SPAD index in the R2 and R5.2 stages (Table 2). The fallow treatment, however, resulted in the lowest soybean biomass in R2. In general, the autumn/winter treatments had less impact on soybean growth in $2018 / 2019$ than in 2017/2018.

Despite the differences in soybean growth (Table 1), grain yield was not influenced by the treatments in the 2017/2018 crop season (Table 3). In addition, as water 


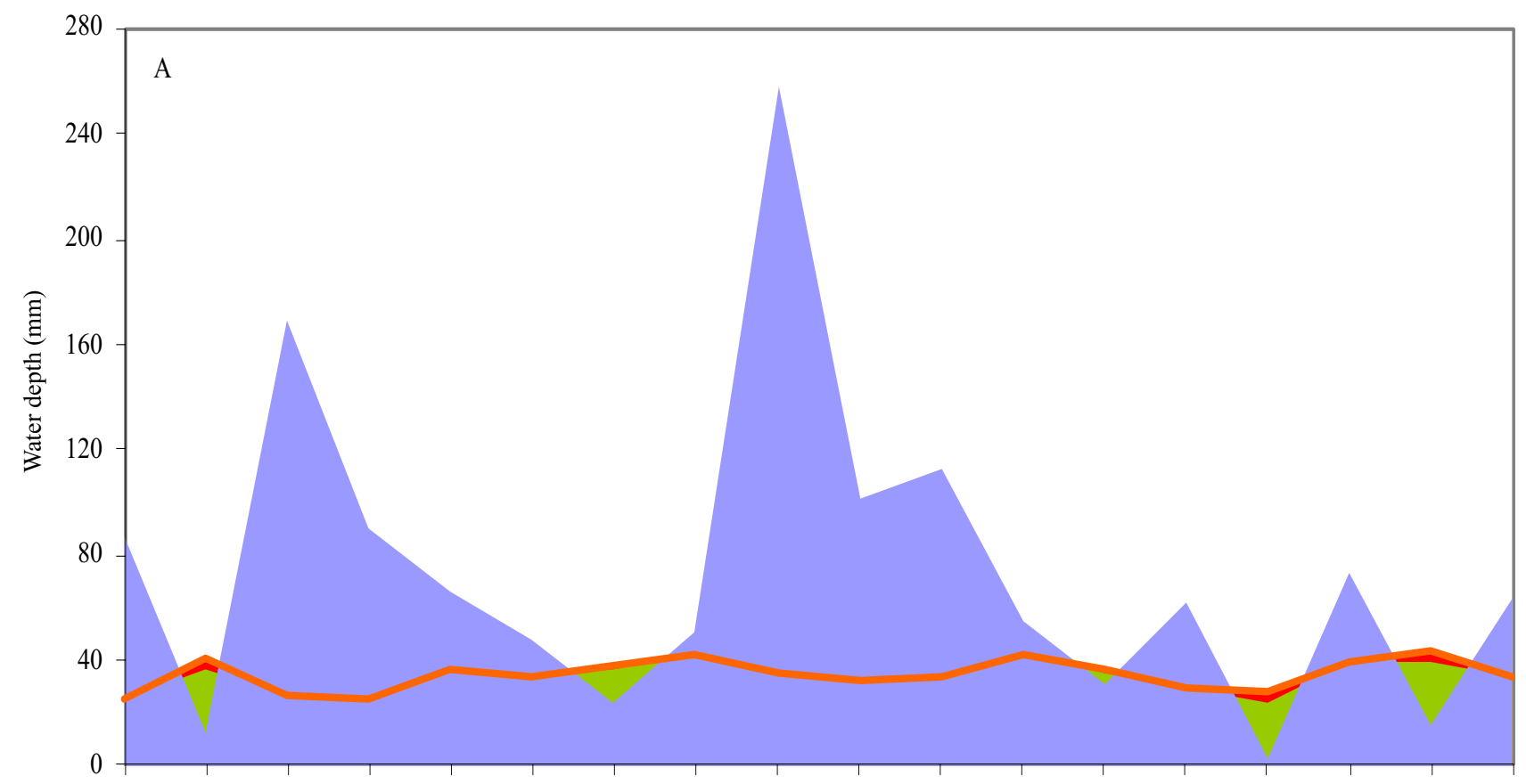

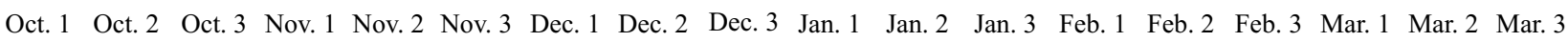

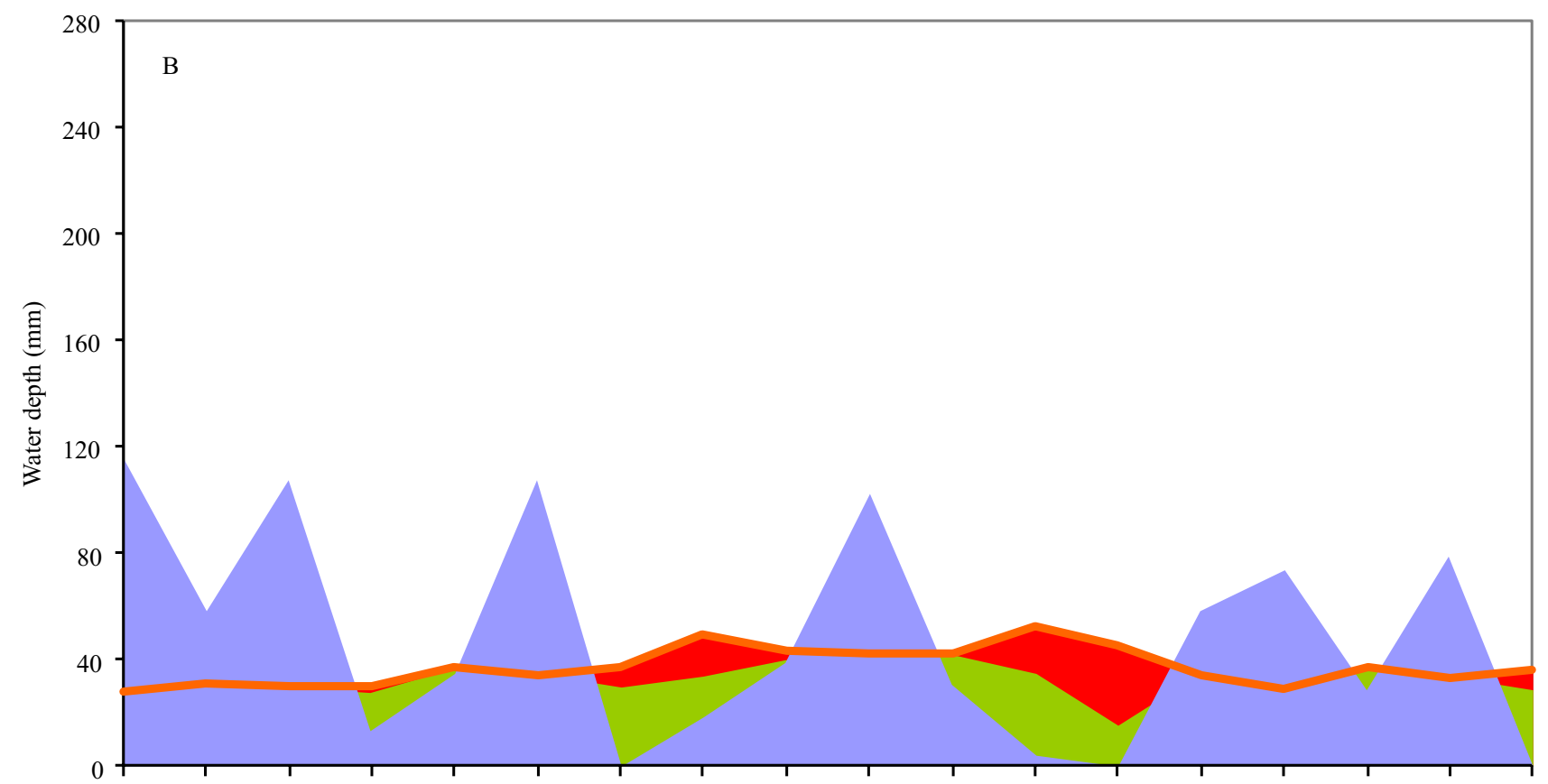

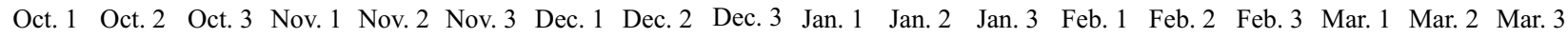
Ten day periods

\begin{tabular}{|ll|}
\hline Deficit $\quad$ Withdrawal $\quad$ Rainfall $\quad$ Potential evapotranspiration \\
\hline
\end{tabular}

Figure 1. Sequential water balance by Thornthwaite \& Mather (1955) from October to March in the experimental area, in the 2017/2018 (A) and 2018/2019 (B) crop seasons, in the municipality of Londrina, in the state of Paraná, Brazil. 
Table 1. Soybean (Glycine max) growth as affected by isolated or combined straw and roots of black oat (Avena strigosa) and 'BRS Pardela' wheat (Triticum aestivum), as previous crops in the R1 and R4 phenological stages, in the 2017/2018 crop season, in Londrina, in the state of Paraná, Brazil ${ }^{(1)}$.

\begin{tabular}{|c|c|c|c|}
\hline Treatment & Leaf area index & $\mathrm{SPAD}^{(2)}$ & Dry matter mass $\left(\mathrm{kg} \mathrm{ha}^{-1}\right)$ \\
\hline \multicolumn{4}{|c|}{ R1 phenological stage } \\
\hline Fallow & $1.98 \mathrm{a}$ & $40.3^{\mathrm{ns}}$ & $1,097 \mathrm{a}$ \\
\hline Black oat straw & $2.13 \mathrm{a}$ & 40.0 & $1,000 \mathrm{a}$ \\
\hline Wheat straw & $1.47 \mathrm{~b}$ & 39.4 & $687 b$ \\
\hline Black oat roots & $2.03 \mathrm{a}$ & 40.5 & $1,260 \mathrm{a}$ \\
\hline Wheat roots & $1.55 \mathrm{~b}$ & 41.4 & $798 b$ \\
\hline Black oat straw and roots & $2.23 \mathrm{a}$ & 40.4 & $1,197 \mathrm{a}$ \\
\hline Wheat straw and roots & $1.50 \mathrm{~b}$ & 38.8 & $850 \mathrm{~b}$ \\
\hline Coefficient of variation (\%) & 19.2 & 3.6 & 18.2 \\
\hline \multicolumn{4}{|c|}{ R4 phenological stage } \\
\hline Fallow & $4.04 \mathrm{a}$ & $39.1^{\mathrm{ns}}$ & $3,132 b$ \\
\hline Black oat straw & $3.94 \mathrm{a}$ & 41.9 & $3,622 \mathrm{a}$ \\
\hline Wheat straw & $3.94 \mathrm{a}$ & 40.5 & $2,693 b$ \\
\hline Black oat roots & $4.45 \mathrm{a}$ & 39.3 & $3,431 \mathrm{a}$ \\
\hline Wheat roots & $4.16 \mathrm{a}$ & 39.7 & $3,426 \mathrm{a}$ \\
\hline Black oat straw and roots & $5.44 \mathrm{a}$ & 40.7 & $3,919 \mathrm{a}$ \\
\hline Wheat straw and roots & $2.70 \mathrm{~b}$ & 38.9 & $3,346 \mathrm{a}$ \\
\hline Coefficient of variation (\%) & 20.4 & 5.1 & 20.6 \\
\hline
\end{tabular}

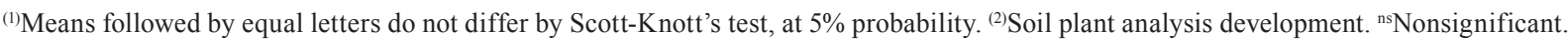

Table 2. Soybean (Glycine max) growth as affected by isolated or combined straw and roots of black oat (Avena strigosa) and 'BRS Pardela' wheat (Triticum aestivum), as previous crops in the R2 and R5.2 phenological stages, in the 2018/2019 crop season, in Londrina, in the state of Paraná, Brazil ${ }^{(1)}$.

\begin{tabular}{|c|c|c|c|}
\hline Treatment & Leaf area index & $\mathrm{SPAD}^{(2)}$ & Dry matter mass $\left(\mathrm{kg} \mathrm{ha}^{-1}\right)$ \\
\hline \multicolumn{4}{|c|}{ R2 phenological stage } \\
\hline Fallow & $3.50^{\mathrm{ns}}$ & $35.2^{\mathrm{ns}}$ & $1,001 \mathrm{~b}$ \\
\hline Black oat straw & 3.83 & 33.8 & $1,138 \mathrm{a}$ \\
\hline Wheat straw & 3.69 & 35.0 & $1,234 \mathrm{a}$ \\
\hline Black oat roots & 3.63 & 34.2 & $1,292 \mathrm{a}$ \\
\hline Wheat roots & 3.76 & 34.6 & $1,221 \mathrm{a}$ \\
\hline Black oat straw and roots & 4.39 & 35.3 & $1,357 \mathrm{a}$ \\
\hline Wheat straw and roots & 3.68 & 33.9 & $1,222 \mathrm{a}$ \\
\hline Coefficient of variation (\%) & 27.6 & 4.6 & 13.2 \\
\hline \multicolumn{4}{|c|}{ R5.2 phenological stage } \\
\hline Fallow & $4.77^{\mathrm{ns}}$ & $40.6^{\mathrm{ns}}$ & $6,179^{\text {ns }}$ \\
\hline Black oat straw & 5.72 & 40.8 & 5,721 \\
\hline Wheat straw & 5.32 & 41.3 & 5,483 \\
\hline Black oat roots & 5.03 & 39.3 & 5,549 \\
\hline Wheat roots & 5.53 & 39.3 & 5,420 \\
\hline Black oat straw and roots & 6.67 & 39.9 & 6,771 \\
\hline Wheat straw and roots & 6.28 & 40.9 & 5,930 \\
\hline Coefficient of variation (\%) & 19.3 & 5.5 & 20.7 \\
\hline
\end{tabular}

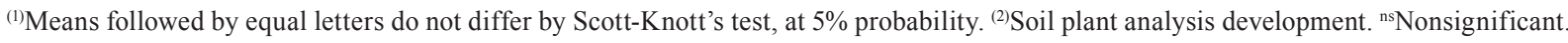


availability was adequate (Figure $1 \mathrm{~A}$ ), the grain yield was high regardless of the treatments. The number of pods per area and the number of grains per pod were also not influenced by any of the treatments. Conversely, grain mass was lowest in the fallow treatment, but with no significant impact on yield. It is possible that adequate water availability during the soybean development cycle reduced the positive effects of the straw and roots of the previous crops on soybean performance, as also reported by Franchini et al. (2012).

In 2018/2019, the lowest soybean yield was observed in the fallow treatment and the highest, on straw plus roots of black oat or wheat (Table 4). The statistical differences between the mean values of soybean yield are likely due to the occurrence of two periods with water deficit in December 2018 and January/February 2019 , associated with the cumulative effects of the treatments over time, as also noted by Pacheco et al. (2017). In this crop season, the component that most influenced yield was grain mass.

In the treatments with straw and roots, grain yield increased by $54 \%$, i.e., $1,467 \mathrm{~kg} \mathrm{ha}^{-1}$, comparatively to that of fallow in the 2018/2019 crop season, clearly showing the positive impacts of black oat and wheat grown in autumn/winter on soybean performance. Therefore, the root effects were proved to be as important as those of straw mulch to explain soybean yield increases in response to black oat or wheat cultivation during autumn/winter (Table 4). In the same region, Balbinot Junior et al. (2017) concluded that, in comparison with fallow, the cultivation of U. ruziziensis or Urochloa brizantha (A.Rich.) R.D.Webster as cover crops, in the period of autumn/ winter, increases soybean grain yield, which is more

Table 3. Soybean (Glycine max) grain yield and yield components as affected by isolated or combined straw and roots of black oat (Avena strigosa) and 'BRS Pardela' wheat (Triticum aestivum), as previous crops, in the 2017/2018 crop season, in Londrina, in the state of Paraná, Brazil ${ }^{(1)}$.

\begin{tabular}{|c|c|c|c|c|}
\hline Treatment & $\begin{array}{c}\text { Yield } \\
\left(\mathrm{kg} \mathrm{ha}^{-1}\right)\end{array}$ & $\begin{array}{c}\text { Number of pods } \\
\text { per } \mathrm{m}^{2}\end{array}$ & $\begin{array}{l}\text { Number of grains } \\
\text { per pod }\end{array}$ & $\begin{array}{c}\text { Thousand-grain } \\
\text { weight }(\mathrm{g})\end{array}$ \\
\hline Fallow & $4,086^{\mathrm{ns}}$ & $1,410^{\mathrm{ns}}$ & $2.09^{\text {ns }}$ & $132 \mathrm{~b}$ \\
\hline Black oat straw & 4,437 & 1,500 & 2.18 & $139 \mathrm{a}$ \\
\hline Wheat straw & 4,328 & 1,343 & 2.18 & $141 \mathrm{a}$ \\
\hline Black oat roots & 4,563 & 1,532 & 2.00 & $147 \mathrm{a}$ \\
\hline Wheat roots & 4,479 & 1,603 & 1.97 & $150 \mathrm{a}$ \\
\hline Black oat straw and roots & 4,642 & 1,554 & 2.05 & $152 \mathrm{a}$ \\
\hline Wheat straw and roots & 4,479 & 1,586 & 2.04 & $149 \mathrm{a}$ \\
\hline Coefficient of variation (\%) & 7.0 & 14.6 & 6.0 & 4.2 \\
\hline
\end{tabular}

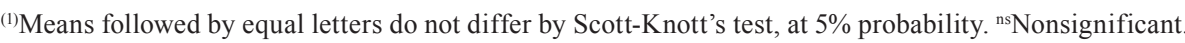

Table 4. Soybean (Glycine max) grain yield and yield components as affected by isolated or combined straw and roots of black oat (Avena strigosa) and 'BRS Pardela' wheat (Triticum aestivum), as previous crops, in the 2018/2019 crop season, in Londrina, in the state of Paraná, Brazil ${ }^{(1)}$.

\begin{tabular}{|c|c|c|c|c|}
\hline Treatment & $\begin{array}{c}\text { Yield } \\
\left(\mathrm{kg} \mathrm{ha}^{-1}\right)\end{array}$ & $\begin{array}{c}\text { Number of pods } \\
\text { per } \mathrm{m}^{2}\end{array}$ & $\begin{array}{c}\text { Number of grains } \\
\text { per pod }\end{array}$ & $\begin{array}{c}\text { Thousand-grain } \\
\text { weight (g) }\end{array}$ \\
\hline Fallow & $2,692 \mathrm{c}$ & $1,173^{\text {ns }}$ & $2.42^{\text {ns }}$ & $116 \mathrm{~b}$ \\
\hline Black oat straw & $3,456 b$ & 1,257 & 2.49 & $124 b$ \\
\hline Wheat straw & $3,608 b$ & 1,212 & 2.49 & $135 \mathrm{a}$ \\
\hline Black oat roots & $3,503 b$ & 1,183 & 2.53 & $130 \mathrm{a}$ \\
\hline Wheat roots & $3,513 b$ & 1,257 & 2.44 & $124 b$ \\
\hline Black oat straw and roots & $4,142 \mathrm{a}$ & 1,420 & 2.45 & $140 \mathrm{a}$ \\
\hline Wheat straw and roots & $4,176 \mathrm{a}$ & 1,376 & 2.47 & $139 a$ \\
\hline Coefficient of variation $(\%)$ & 11.4 & 15.3 & 4.2 & 7.8 \\
\hline
\end{tabular}

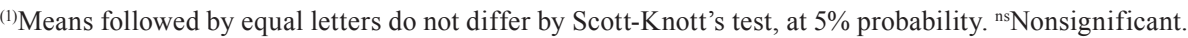


expressive due to the impact of Urochloa spp. roots than straw.

In the 2018/2019 crop season, the treatments impacted soybean yield (Table 4), but had little effect on plant growth (Table 2). Therefore, it is possible to infer that the positive effects of straw and roots on soybean yield are mainly associated with the reduction of water stress observed during the grain-filling period (Figure $1 \mathrm{~B}$ ). The higher grain mass in the treatments with straw and roots reinforces this hypothesis. From this point of view, the positive effects of black oat or wheat roots on soybean yield may be primarily due to soil structure improvement. Accordingly, the root growth of previous crops contributes to fracture compacted layers (Moraes et al., 2018a) and create a complex network of continuous and stable biopores (Rosolem \& Pivetta, 2017). It is well known that biopores produced by previous crops play an important role in increasing soil water infiltration, hydraulic conductivity, and gas diffusion, providing higher water and oxygen availability to subsequent crop roots (Kautz, 2015; Moraes et al., 2016). Moreover, the improved soil structure reduces soil mechanical impedance, enhancing soybean rooting and water uptake from deeper layers (Moraes et al., 2018a). Besides creating biopores, roots improve soil physical quality by increasing organic matter content and the effects of wetting-drying cycles on soil structure recovery (Bonetti et al., 2017; Ferreira et al., 2018).

Straw mulch of crops also increases soil water storage (Moraes et al., 2018b), since it reduces losses by evaporation (Dahiya et al., 2007) and runoff (Engel et al., 2009). A higher water content lowers soil mechanical resistance to penetration and, consequently, increases root growth (Moraes et al., 2018a). Therefore, straw retention on soil surface probably increased water availability to soybean plants, alleviating the negative impacts of the water deficit periods of 2018/2019 on soybean yield. Straw retention also reduces soil temperature (Dalmago et al., 2010; Siczek et al., 2015), providing a better environment for soybean root growth and functioning - both strongly impacted by high soil temperatures (Kaspar \& Bland, 1992) -, increasing plant water use efficiency and grain yield.

Another factor likely related to the positive effects of black oat or wheat straw and roots on soybean performance is an increased biological nitrogen fixation (BNF). In a comprehensive review, Hungria
\& Vargas (2000) indicated both water deficit and high soil temperatures as major environmental factors impairing BNF under tropical conditions. According to Justino \& Sodek (2013), BNF is also strongly impaired by a low oxygen supply to roots and nodules. Since roots and straw contribute to enhance soil physical quality, these environmental stresses are expected to be lower in soils cultivated with black oat and wheat as previous crops, resulting in a higher BNF and, consequently, soybean yield. Likewise, Sindelar et al. (2016) also concluded that BNF is favored under highquality soils, usually associated with large organic matter inputs into the soil.

The present study also showed that the effects of black oat and wheat on soybean yield were similar, despite the great morphophysiological differences between the species. However, wheat grains can be produced in autumn/winter without soybean yield losses, compared with the use of black oat as a cover crop. Conversely, the removal of black oat or wheat shoots for silage or hay production can reduce the benefits of these crops on subsequent soybean yield by approximately $50 \%$. Such information should be considered in the decision-making process regarding the cropping system to be adopted at farms.

\section{Conclusions}

1. Cultivating black oat (Avena strigosa) or wheat (Triticum aestivum) as previous crops during autumn/ winter increases soybean (Glycine max) grain yield in comparison with fallow.

2. The impact of the roots of black oat and wheat on soybean yield is similar to that of straw.

3. The combination of the roots and straw of black oat or wheat promotes the best soybean agronomic performance.

\section{Acknowledgments}

To Conselho Nacional de Desenvolvimento Científico e Tecnológico (CNPq), for granting a fellowship of productivity to the first author (process number 304752/2016-9).

\section{References}

BALBINOT JUNIOR, A.A.; MORAES, A. de; VEIGA, M. da; PELISSARI, A.; DIECKOW, J. Integração lavoura-pecuária: 
intensificação de uso de áreas agrícolas. Ciência Rural, v.39, p.1925-1933, 2009. DOI: https://doi.org/10.1590/S010384782009005000107.

BALBINOT JUNIOR, A.A.; SANTOS, J.C.F. dos; DEBIASI, H.; YOKOYAMA, A.H. Contribution of roots and shoots of Brachiaria species to soybean performance in succession. Pesquisa Agropecuária Brasileira, v.52, p.592-598, 2017. DOI: https://doi.org/10.1590/s0100-204x2017000800004.

BALBINOT JUNIOR, A.A.; VEIGA, M. da.; MORAES, A. de; PELISSARI, A.; MAFRA, A.L.; PICCOLLA, C.D. Winter pasture and cover crops and their effects on soil and summer grain crops. Pesquisa Agropecuária Brasileira, v.46, p.1357-1363, 2011. DOI: https://doi.org/10.1590/S0100-204X2011001000032.

BONETTI, J. de A.; ANGHINONI, I.; MORAES, M.T. de; FINK, J.R. Resilience of soils with different texture, mineralogy and organic matter under long-term conservation systems. Soil \& Tillage Research, v.174, p.104-112, 2017. DOI: https://doi.org/10.1016/j.still.2017.06.008.

CALONEGO, J.C.; GIL, F.C.; ROCCO, V.F.; SANTOS, E.A. dos. Persistência e liberação de nutrientes da palha de milho, braquiária e labe-labe. Bioscience Journal, v.28, p.770-781, 2012.

CALONEGO, J.C.; RAPHAEL, J.P.A.; RIGON, J.P.G.; OLIVEIRA NETO, L. de; ROSOLEM, C.A. Soil compaction management and soybean yields with cover crops under no-till and occasional chiseling. European Journal of Agronomy, v.85, p.31-37, 2017. DOI: https://doi.org/10.1016/j.eja.2017.02.001.

DAHIYA, R.; INGWERSEN, J.; STRECK, T. The effect of mulching and tillage on the water and temperature regimes of a loess soil: experimental findings and modelling. Soil \& Tillage Research, v.96, p.52-63, 2007. DOI: https://doi.org/10.1016/j. still.2007.02.004.

DALMAGO, G.A.; BERGAMASCHI, H.; KRÜGER, C.A.M.B.; BERGONCI, J.I.; COMIRAN, F.; HECKLER, B.M.M. Evaporação da água na superfície do solo em sistemas de plantio direto e preparo convencional. Pesquisa Agropecuária Brasileira, v.45, p.780-790, 2010. DOI: https://doi.org/10.1590/ S0100-204X2010000800002.

DERPSCH, R.; FRANZLUEBBERS, A.J.; DUIKER, S.W.; REICOSKY, D.C.; KOELLER, K. Why do we need to standardize no-tillage research? Soil \& Tillage Research, v.137, p.16-22, 2014. DOI: https://doi.org/10.1016/j.still.2013.10.002.

ENGEL, F.L.; BERTOL, I.; RITTER, S.R.; PAZ GONZÁLEZ, A.; PÁZ-FERREIRO, J.; VIDAL VÁZQUEZ, E. Soil erosion under simulated rainfall in relation to phenological stages of soybeans and tillage methods in Lages, SC, Brazil. Soil \& Tillage Research, v.103, p.216-221, 2009. DOI: https://doi.org/10.1016/j. still.2008.05.017.

FEHR, W.R.; CAVINESS, C.E. Stages of soybean development. Ames: Iowa State University, 1977. 11p. (Special report, 80).

FERREIRA, A. de O.; SÁ, J.C. de M.; LAL, R.; TIVET, F.; BRIEDIS, C.; INAGAKI, T.M.; GONÇALVES, D.R.P.; ROMANIW, J. Macroaggregation and soil organic carbon restoration in a highly weathered Brazilian Oxisol after two decades under no-till. Science of the Total Environment, v.621, p.15591567, 2018. DOI: https://doi.org/10.1016/j.scitotenv.2017.10.072.
FERREIRA, D.F. Sisvar: um programa para análises e ensino de estatística. Revista Symposium, v.6, p.36-41, 2008.

FRANCHINI, J.C.; DEBIASI, H.; BALBINOT JUNIOR, A.A.; TONON, B.C.; FARIAS, J.R.B.; OLIVEIRA, M.C.N. de; TORRES, E. Evolution of crop yields in different tillage and cropping systems over two decades in Southern Brazil. Field Crops Research, v.137, p.178-185, 2012. DOI: https://doi.org/10.1016/j.fcr.2012.09.003.

HUNGRIA, M.; VARGAS, M.A.T. Environmental factors affecting $\mathrm{N}_{2}$ fixation in grain legumes in the tropics, with an emphasis on Brazil. Field Crops Research, v.65, p.151-164, 2000. DOI: https://doi.org/10.1016/S0378-4290(99)00084-2.

JUSTINO, G.C.; SODEK, L. Recovery of nitrogen fixation after short-term flooding of the nodulated root system of soybean. Journal of Plant Physiology, v.170, p.235-241, 2013. DOI: https://doi.org/10.1016/j.jplph.2012.10.006.

KASPAR, T.C.; BLAND, W.L. Soil temperature and root growth. Soil Science, v.154, p.290-299, 1992. DOI: https://doi.org/10.1097/00010694-199210000-00005.

KAUTZ, T. Research on subsoil biopores and their functions in organically managed soils: a review. Renewable Agriculture and Food Systems, v.30, p.318-327, 2015. DOI: https://doi.org/10.1017/ S1742170513000549.

KRENCHINSKI, F.H.; CESCO, V.J.S.; RODRIGUES, D.M.; ALBRECHT, L.P.; WOBETO, K.S.; ALBRECHT, A.J.P. Agronomic performance of soybean grown in succession to winter cover crops. Pesquisa Agropecuária Brasileira, v.53, p.909-917, 2018. DOI: https://doi.org/10.1590/s0100-204x2018000800005.

MORAES, M.T. de; BENGOUGH, A.G.; DEBIASI, H.; FRANCHINI, J.C.; LEVIEN, R.; SCHNEPF, A.; LEITNER, D. Mechanistic framework to link root growth models with weather and soil physical properties, including example applications to soybean growth in Brazil. Plant and Soil, v.428, p.67-92, 2018a. DOI: https://doi.org/10.1007/s11104-018-3656-z.

MORAES, M.T. de; DEBIASI, H.; CARLESSO, R.; FRANCHINI, J.C.; SILVA, V.R. da; LUZ, F.B. da. Soil physical quality on tillage and cropping systems after two decades in the subtropical region of Brazil. Soil \& Tillage Research, v.155, p.351-362, 2016. DOI: https://doi.org/10.1016/j.still.2015.07.015.

MORAES, M.T. de; DEBIASI, H.; FRANCHINI, J.C. Modelagem da dinâmica da água em sistemas de preparo de um Latossolo Vermelho. Scientia Agraria, v.19, p.142-152, 2018b. DOI: https://doi.org/10.5380/rsa.v19i1.52216.

MUNKHOLM, L.J.; HECK, R.J.; DEEN, B. Long-term rotation and tillage effects on soil structure and crop yield. Soil \& Tillage Research, v.127, p.85-91, 2013. DOI: https://doi.org/10.1016/j. still.2012.02.007.

PACHECO, L.P.; SÃO MIGUEL, A.S.D.C.; SILVA, R.G. da; SOUZA, E.D. de; PETTER, F.A.; KAPPES, C. Biomass yield in production systems of soybean sown in succession to annual crops and cover crops. Pesquisa Agropecuária Brasileira, v.52, p.582-591, 2017. DOI: https://doi.org/10.1590/s0100$204 \times 2017000800003$. 
PISSINATI, A.; MOREIRA, A.; SANTORO, P.H. Biomass yield and nutrients concentration in shoot dry weight of winter cover crops for no-tillage system. Communications in Soil Science and Plant Analysis, v.47, p.2292-2305, 2016. DOI: https://doi.org/10.1080/00103624.2016.1243711.

ROSOLEM, C.A.; PIVETTA, L.A. Mechanical and biological approaches to alleviate soil compaction in tropical soils: assessed by root growth and activity ( $\mathrm{Rb}$ uptake) of soybean and maize grown in rotation with cover crops. Soil Use and Management, v.33, p.141-152, 2017. DOI: https://doi.org/10.1111/sum.12313.

SANTOS, H.G. dos; JACOMINE, P.K.T.; ANJOS, L.H.C. dos; OLIVEIRA, V.A. de; LUBRERAS, J.F.; COELHO, M.R.; ALMEIDA, J.A.; CUNHA, T.J.F.; OLIVEIRA, J.B. de. Sistema brasileiro de classificação de solos. 3.ed. rev. e ampl. Brasília: Embrapa, 2013. 353p.

SICZEK, A.; HORN, R.; LIPIEC, J.; USOWICZ, B.; ŁUKOWSKI, M. Effects of soil deformation and surface mulching on soil physical properties and soybean response related to weather conditions. Soil \& Tillage Research, v.153, p.175-184, 2015. DOI: https://doi.org/10.1016/j.still.2015.06.006.
SINDELAR, A.J.; SCHMER, M.R.; JIN, V.L.; WIENHOLD, B.J.; VARVEL, G.E. Crop rotation affects corn, grain sorghum, and soybean yields and nitrogen recovery. Agronomy Journal, v.108, p.1592-1602, 2016. DOI: https://doi.org/10.2134/ agronj2016.01.0005.

SOIL SURVEY STAFF. Keys to soil taxonomy. $11^{\text {th }}$ ed. Washington: USDA, NRCS, 2010.

THORNTHWAITE, C.W.; MATHER, J.R. The water balance. Centerton: Drexel Institute of Technology, 1955. $104 \mathrm{p}$. (Climatology, v.8, n.1).

WOLSCHICK, N.H.; BARBOSA, F.T.; BERTOL, I.; SANTOS, K.F. dos; WERNER, R. de S.; BAGIO, B. Cobertura do solo, produção de biomassa e acúmulo de nutrientes por plantas de cobertura. Revista de Ciências Agroveterinárias, v.15, p.134143, 2016. DOI: https://doi.org/10.5965/223811711522016134.

YOKOYAMA, A.H.; RIBEIRO, R.H.; BALBINOT JUNIOR, A.A.; FRANCHINI, J.C.; DEBIASI, H.; ZUCARELI, C. Índices de área foliar e SPAD da soja em função de culturas de entressafra e nitrogênio e sua relação com a produtividade. Revista de Ciências Agrárias, v.41, p.953-962, 2018. DOI: https://doi.org/10.19084/RCA18153. 